\title{
The Flip Side of Kenya's Postcolonial Autocratic Rule in Ngugi Wa Thiong'o's Devil on the Cross (1982)
}

\author{
Noha Ahmed Abdelaziz \\ Department of English, Faculty of Al-Alsun (Languages), Minia University \\ noha.abdelaziz@mu.edu.eg
}

Received: June 12, 2020 Accepted: August 18, 2020 Published: October 26, 2020

\begin{abstract}
:
Life in post-colonial Kenya is characterized by various aspects of corruption and disintegration resulting from the hegemony of the kleptocratic government of Kenya. Based on Antonio Gramsci's discussion of the notion of hegemony, and out of Aschcroft, Griffiths, and Tiffin's definition of the process of decolonization, the paper sheds light upon the ignominious status of Kenya after independence and the efforts of the Kenyan masses to resist and regain their stolen country. Through Ngugi Wa Thiong's Devil on the Cross, the research exposes the exploitation policies of the native rulers in postcolonial Kenya and their role in suppressing the hopes and volitions of the miserable people. As a Kenyan writer, Ngugi Wa Thiong'o devotes most of his works for criticizing the Kenyan leaders' rule and shows their intractable intentions to spread different forms of corruption all over Kenya on account of realizing their illegal objectives.
\end{abstract}

Keywords: Kleptocracy, postcolonial Kenya, class-struggle, policy of resistance, social injustice, capitalism

\section{Introduction}

Undoubtedly, the corruption and oppression of any country's ruling regime call necessarily for its retardation and underdevelopment. Kenya is one of those countries which fall victim to the corruption of their rulers, leaders, and other governmental members. After its independence in 1963, the keys of power are directed to the bourgeoisie class of people 
who adopt the same policy of hegemony used by the bygone white colonizers. Thus, "by the early 1960s, the stage was set for the transition to independence under the hegemony of the indigenous bourgeoisie. The indigenous bourgeoisie proceeded to use state power to further their control over the means of production, at the same time purging any radical elements within the ruling party, KANU [The Kenya African National Union]" [Brackets mine] (Swainson, 1980, p.16).

This research aims at spotting light upon the different strategies of corruption which resulted from the hegemonic power of the Kenyan regime after independence. Furthermore, the emergence of the bourgeois people's hegemony in Kenya was met by a kind of national resistance whose aim was to regain the Kenyan identity, destroy the colonial existence and emphasize the African heritage and authenticity. This kind of national resistance is exemplified in the decolonization process. As the policy of hegemony practiced by the indigenous bourgeoisie and their government is a continuation and a result of the foreign colonization period, the process of decolonization comes to annihilate and erase any trace that may be related to this period of time. Based on Antonio Gramsci's analysis of the concept of hegemony, and out of Aschcroft, Griffiths and Tiffin's definition of the process of decolonization, the research examines the nature of the indigenous ruling system of postcolonial Kenya and the ways of its opposition through handling Ngugi Wa Thiong'o's Devil on the Cross.

\section{Discussion}

Antonio Gramsci (1891-1937) was one of the political theorists and cultural critics who celebrated in the twentieth century. He was also a member of the Communist Party in Italy. He stressed the important role of the working class to revolt and oppose the domination of the ruling class and how they can proceed to gain power. He, moreover, confirmed the notion of hegemony by consent, where the subordinate class accepts the ideas, values, and leadership of the ruling one on account of some fraud concessions granted by the ruling class. In this way, Gramsci declares his difference from the classic Marxist approach which stresses the role of using force and coercion as the cornerstone of the ruling class 
hegemony. Gramsci's perspective of the relation between the ruling class and the subordinate one can be highly represented through the words of Johnny E. Williams (2000) who expresses:

Gramsci understood hegemony as the conditions necessary in any given society for the achievement and consolidation of rule. The ruling class consolidates its control over subordinates through systems of ideas and practices that are elaborated and maintained through such social mechanisms as everyday interactions, the media, politics, family and education. After subordinates are persuaded that the existing system of ideas is fair or natural, these ideas become their common sense ways of thinking and acting that legitimate the way society is organized. (p. 218)

Furthermore, the Kenyan bourgeoisie sticks to the system of capitalism as it is the successful strategy used by the former foreign colonizers during their rule in Kenya, and in other words, it is the preferred system through which the Kenyan bourgeoisie can attain the greatest possible profits without any kind of control. Hence, according to Harold Entwistle (2002), the concept of hegemony concerning the capitalist society is clarified where:

... In capitalist societies, the bourgeoisie is hegemonic in relation to the peasantry and industrial working class. In its turn, the point of socialist revolution is counter-hegemonic, aimed at replacing bourgeois by proletarian hegemony. However, of particular educational importance is the fact that hegemonic control is not exercised through physical (i.e., military or police) or legal coercion. Subaltern are persuaded to see maintenance of the status quo as being in their own best interests: bourgeois hegemony depends upon this "false consciousness" of the working class. Indeed, erosion of active consent to the status quo and resort to force by the ruling class would already be an indication of collapse of the existing hegemony. (p. 252)

In relevance to Gramsci's analysis of the concept of hegemony, the postcolonial writer Ngugi Wa Thiong'o plays a pivotal role in picturing the various features of corruption that arise from the hegemony of the indigenous leaders of Kenya and their strenuous efforts to subdue all the apparatuses of the country for their sake. Through his fictional work, Devil on the Cross (1982), Ngugi criticizes satirically the politics of the Kenyan elite after independence. The novel which is secretly written on toilet papers' sheets during the imprisonment of Ngugi in Kimathi prison, addresses the novelist's farewell to writing in English. It is Ngugi's first novel to be written in his native language, the Gikuyu, under the title Caitaani Mutharaba-inuin. 
Throughout the character of Wariinga, the author demonstrates the different kinds of social oppression that people of Kenya, especially women, were subjected to. From the first pages of the novel, Wariinga appears to be facing many troubles. She is entrapped by a rich old man from Ngorika who impregnates her and leaves her to face the unknown fate. When she goes to Nairobi to search for a job opportunity, she discovers that the businessmen and other managers of big companies exploit the purity of the job seekers girls and grant them jobs only in return for some notorious relationships. In new Kenya, Wariinga or Kareendi, her English name, discovers that attaining one's simplest rights must have a return. She enters many offices and in every one of them, she meets Mr. Boss who looks at her from top to toe and tells her "Ah Kareendi, jobs are very hard to come by these days. But a girl like you ... it shouldn't be too difficult to find something for you to do. But, Kareendi, a matter like this can't be finalized in the office. Let's go across to the Modern Love Bar and Lodging to discuss the question more fully" (Wa Thiong'o, 1982, p. 19). Wariinga understands the message of Mr. Boss, so she decides to try another office, but unfortunately "she enters another office. She finds there another Mr. Boss. The smiles are the same, the questions are the same, the rendezvous is the same - and the target is still Kareendi's thighs. The Modern Love Bar and Lodging has become the main employment bureau for girls, and women's thighs are the tables on which contracts are signed" (Wa Thiong'o, 1982, p. 19). Through the previous words, Ngugi mirrors the disease of sexual harassment and presents the scandalous ethical corruption of the Kenyan society during the rule of black leaders who give themselves the full right to control the life of others.

Failing to find a job in Nairobi, Wariinga decides to return to Illmorog. She gets onto a matatu, the only means of transportation to Illmorog. In the matatu, Wariinga recognizes other characters; Wangari, Gaturia, Muturi, and Mwaura, whose life elucidates the severe nature of the Kenyan society at that time. For example, Wangari is an old woman who represents a victim of postcolonial Kenya. She is one of those miserable people who do not even have the fare of the matatu. Although she was one of those who "fought for this country's independence with [her] 
hands" (Wa Thiong'o, 1982, p. 37), she is suppressed and humiliated by this new Kenyan system. But it is apparent that most Kenyan people know well the bitter fact of their new Kenya. So, Mwaura, the simple driver, summarizes to Wangari the status of Kenya after independence saying: "[ $\mathrm{t}]$ hese days the land rewards not those who clear it but those who come after it has been cleaned" (Wa Thiong'o, 1982, p. 37). The words of Mwaura enhance Ngugi's suggestion that the new African leaders alleged falsely their resistance to the foreign colonization of Africa, but they are in reality just some watchdogs "who perpetuated Western domination and thus were nothing but pawns of the white man whose presence on the African continent was no longer endurable" (Abis, 2011, p. 1).

Wangari had a small piece of land which was her only source of living and which was auctioned by the Kenya Economic Progress Bank for failing to give back the loan. Consequently, she decides to search for any job in Nairobi, but her efforts become in vain. Increasingly, she "... was taken to court this morning, charged with intending to steal and with roaming about Nairobi without being a resident of the city, without a job, without a house and without a permit" (Wa Thiong'o, 1982, p. 43).

Astoundingly, Wangari is detained for roaming and searching for a job in the streets of Nairobi without permission to enter the city. The Kenyan citizen is treated within his homeland like a foreigner. The black leaders after independence consider the capital of the country as their personal fenced possession; hence, poor people have no permission to enter it. So, Wangari asks astonishingly "I, Wangari, a Kenyan by birth — how can I be a vagrant in my own country? How can I be charged with vagrancy in my own country as if I were a foreigner?" (Wa Thiong'o, 1982, p. 43). The words of Wangari prove that the black rule after independence did not differ from that of the foreign one before independence. The Kenyan people's sense of displacement in which they lived many years during the colonization, persists even during the rule of the native governors. On the other hand, "Depriving migrant workers of their right to move freely throughout the country is one way to cut their possibilities of access of employment and bring upon them more poverty" (Sylla, 2009). 
On the other hand, through adopting the policy of persuasive hegemony, the black ruling system convinces the majority that anyone who may oppose its laws or criticize its policies is an enemy of the state and so he/she should be imprisoned in order to protect the state and other people of his/her evils. Consequently, the ruling system's hegemony contains necessarily a kind of suppression and subjugation as a means to ensure its continuation in authority. This fact is obviously proved through Devil on the Cross where the major characters announce that the only safe place in which they can speak freely is the matatu where no one can observe or monitor them. They cannot talk to each other openly about the abuses of the ruling system or the goals which it has achieved since the day of independence. When Gatuiria hesitantly wanted to ask Mwaura a question, Mwaura answered him:

'Go ahead, ask!' Mwaura encouraged him. 'No one's jailed for asking questions!' 'Ah, but in the Kenya of today?' Muturi muttered. 'Don't worry,' Mwaura encouraged Gatuiria. 'When you are inside Mwaura's Matatu Matata Matamu Model T Ford, you are in the heartland of democracy!' 'Oh, yes, there you are right,' Wangari supported him. 'Matatus are the only places left where people can discuss things freely. In a matatu you can speak your thoughts without first looking over your shoulder to see who is listening.' (Wa Thiong'o, 1982, p. 56)

The freedom of opinion is not entitled to the Kenyan citizen under the black rule. He should only be ordered to obey and he has no right to object.

Actually, Ngugi portrays the elements of corruption caused by the capitalistic system of Kenya after independence at their peak when it is evident in the novel that the characters in the matatu receive invitations to attend the devil's feast. The devil's feast is mainly a competition arranged with the organization for Modern Theft and Robbery in Illmorog with the attendance of foreign guests from the international organization for thieves and robbers in the Western world. In a satirical way:

... the reader is asked to believe in a satiric world in which loud-mouthed villains assert their own villainy, a villainy which is exultantly sabotaging the well-being of the whole nation on the platform, each competitor brags about as much as they can their own criminality, combined with the enormity of the universal embezzlement they proudly insist on having engineered. (Sylla, 2009) 
Through the novel, the author employs satirical allegory through which he presents the different tricks of the competitive thieves to refer implicitly to the various ways of exploiting the state's wealth by the black capitalists. Thus, out of using allegory, the novelist pays the reader's attention to the various schemes through which the corrupted masters of the developing countries accumulate their wealth and deceive their people. In the competition:

Contestants vie to prove their prowess as robbers and thieves: not petty thieves, but on an 'international' scale, "those who steal because their bellies are full". The competition among thieves is full of bitter satire as they reveal themselves to be rapacious exploiters, cunning and unrepentant ... They measure their worth in houses, cars, mistresses and conspicuous consumption of food and alcohol. Their rise to wealth has been smoothed by the maneuvering of their fathers before and after independence. They have used the methods of the whites and sold themselves as front men for white businesses who need black faces to continue to exploit the people of Kenya. (Greenfield, 1995, p. 38)

During the competition, every thief has to confess his different ways of stealing and benefiting from the country's wealth. For example, one of the thieves takes cunning as the best weapon for exploiting people. According to him, "wealth is not the work of one's hands but the cunning of one's mind, cunning in a free market system to rob people of the fruits of freedom" (Wa Thiong'o, 1982, p. 105). Moreover, Gitutu Wa Gataanguru sees that the good cunning grabber is the one who should seize the opportunity of the country's famine and thirst. “... hunger humiliated by thirst brings about mass famine, and mass famine is the source of the wealth of a cunning grabber" (Wa Thiong'o, 1982, p. 105).

The idea of this thief in exploiting the poor people refers to the cunning and slyness of the black leaders and their desire to make the masses live a miserable life while they are enjoying the masses' sweat and effort. The black leaders plan to make their people think only of how they can attain food, drink, shelter, and jobs. In this way, the poor people indulge in their problems and forget about the illegal deeds of their black masters. "Thus, the political elite's concern is to deprive the masses of everything so that they will rely on them forever. The masses will sink into deeper poverty and in a position of weakness; they will always need the elite's help to survive" (Diaw, 2006, p. 33). 
Another thief pays attention to the cause of education. He thinks of making some nursery schools with the employment of an aged or crippled white woman and "buying white mannequins to stand in for real white children" (Wa Thiong'o, 1982, p. 113). The existence of the white woman and the white mannequins will convince the high-class Kenyan families that the study in these nursery schools depends upon the English only. There will be no place for the Gikuyu or Kiswahili languages. Regrettably, in postcolonial Kenya, the English language is a sign of civilization and development while the native one is an indication of retardation and underdevelopment. The corrupted notion of this thief, Kihaahu Wa Gatheeca, points out to the black masters' support of the Western culture and its development in Kenya, and their apathy to reinforce the native language and its value among people.

On the other hand, this thief sees that entering parliament is a very important target to be one of those who own the keys to power. Through false promises of reforms and bribing some people to praise him and invent stories of how he was one of those fighters for freedom, Kihaahu Wa Gatheeca can be one of those important parliamentarians. The importance of joining parliament according to this thief expresses the desire of the Kenyan leaders to occupy all the seats of the country's parliament to have more strength and be the only ones who decide the fate of their people.

Moreover, the third thief considers that developing the country is dependent upon regulating births. Mwireri Wa Mukiraai sees that the wives of the poor should not give birth to many children as long as they cannot feed them. According to him, "[i]f a man is without a job, then let him not burden himself with women and children" (Wa Thiong'o, 1982, p. 161). The same concept is adopted by the postcolonial Kenyan leaders who, instead of saving a good standard of living for their people, they call them constantly for regulating births in order to be able to live.

The last thief, Kimeendeeri Wa Kanyuanjii, is the potential one to be crowned as "the king of modern theft, robbery and service of foreigners" (Wa Thiong'o, 1982, p. 187). Through the personality of this thief, Ngugi spots light upon all the corrupted stratagems that were used by the 
Kenyan elite after independence. The novelist embodies and uses the tricks of this thief as an allusion of the black leaders' exploitation and their social disintegration in Kenya after independence. He is the suggested one to be the king of the thieves because his ideas and deeds depend on exploiting the sweat and blood of the poor people in all aspects of life. So, in Devil on the Cross it is stated that:

The ideas that will win him his victory over the other thieves and robbers show quite clearly that Kimeendeeri understands that the sweat and the blood of the workers are the wellsprings of wealth. Kimeendeeri is not even attempting to disguise the fact. He is telling the other delegates: 'Our drinking of the blood of the workers, our milking of their sweat, our devouring of their brains - these three activities should be put on a scientific basis.' (Wa Thiong'o, 1982, p. 187)

Depending on building churches and mosques, Kimeendeeri can impress the religious inclination of the workers. He will employ some priests who urge the workers to obey the masters to have the satisfaction of God. "Every Sunday the workers will be read sermons that will instruct them that the system of milking human sweat, human blood and human brains - the system of the robbery of human labor power and human skills - is ordained by God, and that it has something to do with the eventual salvation of their souls" (Wa Thiong'o, 1982, p. 188).

Moreover, Kimeendeeri will build schools in which children of the workers are taught to "glorify the system of drinking human blood and eating human flesh" (Wa Thiong'o, 1982, p. 189). In these schools, children are not allowed to ask questions about the political or economic system of the country. They are also not allowed to inquire about the possibility of changing their standard of living. The corrupted system of Kimeendeeri will influence the whole life of people even their means of entertainment. He will build cinemas in which films that glorify the system and culture of "the drinkers of human blood and eaters of human flesh" (Wa Thiong'o, 1982, p. 189) will be shown. Even the newspapers of Kimeendeeri will honor the system of those exploiters and denigrate those who may oppose the policy of this system. Hence, Ngugi makes use of the personality of the vicious Kimeendeeri to sum up the different policies that were practiced by the Kenyan masters after independence under the disguise of persuasive hegemony. He shows clearly how the 
Kenyan government can control the people's life wholly to the extent that people themselves begin to be convinced that this corrupted system works only for their benefit. Therefore:

... the churches, the schools, the poetry, the songs, the cinema, the beer halls, the clubs, the newspapers will all act as brain-washing poisons whose purpose will be to convince the workers that in this world there is nothing as glorious as slavery to the Kimeendeeri class. (Wa Thiong'o, 1982, p. 189)

On the other hand, the competition of the thieves is held in Illmorog with the knowledge of the Kenyan government. Although this kind of competition is a public disintegration, the Kenyan government does not show any objection as long as it serves its relationships with other foreign countries. Besides, "they [the thieves] proclaim openly their criminality and greed vis-à-vis the communal goods. They do not even need to conceal their methods and motives knowing that they have an important hold over the law keepers such as the police and the judiciary" (Diaw, 2006, p. 14).

When Wangari, the simple poor woman, goes to the police in order to fetch them to the place of the competition so they can arrest the thieves, they arrest her instead. According to the postcolonial Kenyan laws, those thieves are not criminals; they are high-class people who arrange competitions to attract the attention of some foreign businessmen so the Kenyan government can benefit from the foreign countries' support and donations. But Wangari, in the eyes of the Kenyan government, is the real criminal because "... she was spreading rumors and hatred and planting seeds of conflict in a country that is committed to peace and stability" (Wa Thiong'o, 1982, p. 195). The police, then, chain Wangari's hands while the superintendent, Gakono, responds to the invitation of the master of ceremonies to sit with the foreign guests and have a glass of whiskey. Consequently, the miserable Wangari feels suppressed as she says "so you, the police force, are the servants of one class only? And to think that I stupidly went ahead and entrusted my love of my country to treacherous rats that love to devour patriotism?" (Wa Thiong'o, 1982, p. 198). It is apparent through the words of Wangari that even the police organization that is supposed to establish justice in the country, works only for the sake of the ruling regime and forgets about those wretched 
ones who are just some beggars wandered about the country to disturb its peace. Hence, Muturi speaks bitterly:

As a worker, I know very well that the forces of law and order are on the side of those who rob the workers of the products of their sweat, of those who steal food and land from the peasants. The peace and the order and the stability they defend with armored cars is the peace and the order and the stability of the rich, who feast on bread and wine snatched from the mouths of the poor-yes, they protect the eaters from the wrath of the thirsty and the hungry. (Wa Thiong'o, 1982, p. 204)

Despite all these aspects of corruption and social injustice, Ngugi has the remedy that lies in the people's continuous struggle and resistance to the regime's corruption. As a writer, in almost all of his works Ngugi lends fundamental importance to the concept of resistance. In his early works, he focused on the role of the Kenyan rebels in resisting the occupation of the British settlers, while in his later works, he stressed his hope in the miserable masses to struggle and put an end to their outrageous Kenyan regime. Consequently, his writings are categorized among the resistance literature which is clearly defined by Barbara Harlow who confirms that: "[r]esistance literature calls attention to itself, and to literature in general, as a political and politicized activity. The literature of resistance sees itself furthermore as immediately and directly involved in a struggle against ascendant or dominant forms of ideological and cultural production" (1987, pp. 28-29).

On the other hand, Ngugi gives great concern to the process of decolonization. For him, the first goal in the decolonization process is enriching the daily tool that people use in speaking, writing, expressing thoughts, and communication. This cardinal tool is represented in language. Ngugi suggests that the decolonization process should begin with decolonizing the mind as the first step. According to him, decolonizing the mind means the liberating of mind from any effect of colonization; that is, the annihilating of colonial memory and the canceling of colonial language. African people should forget their colonial education that places the English language as the one that will measure people's civilization. As a result, Ngugi stops writing in English and begins to write in his native Gikuyu."His novel in Gikuyu, the language of one of Kenya's peoples, is a challenge to the neocolonial 
Kenyan regime which had imprisoned him for his efforts in organizing popular Gikuyu culture, his crime that of the defense of national culture" (Harlow, 1987, p. 126).

Furthermore, according to Ashcroft, Griffiths, and Tiffin, the process of decolonization is defined as:

... the process of revealing and dismantling colonialist power in all its forms. This includes dismantling the hidden aspects of those institutional and cultural forces that had maintained the colonialist power and that remain even after political independence is achieved. Initially in many places in the colonized world, the process of resistance was conducted in terms of institutions appropriated from the colonizing culture itself. This was only to be expected, since early nationalists had been educated to perceive themselves as potential heirs to European political systems and models of culture. (2000, p. 63)

Through the previous quotation, it becomes clear that Ashcroft, Griffiths, and Tiffin consider the decolonization process as the weapon that will dismantle all the traces of colonization and among them those black leaders, whom, they confirm, are the heirs of the colonizing system. Consequently, in Devil on the Cross and other works, the author presents the notion of resistance as an integral part of the work through which he conveys his visions and hopes for a better and peaceful future.

In Devil on the Cross, Ngugi embodies the policy of resistance through the masses' revolution. Muturi, the worker, plays a vital role in urging the people to oppose those exploiters and attack this competition of human devils. He asks Wariinga and Gatuiria:

Are you leaving so soon, when the struggle has only just started? Do you want to miss the extraordinary spectacle of us chasing away the class of exploiters from their den in the cave? Look at our people stamping firmly and proudly on the ground as if they were hearkening to the call of the masses! (Wa Thiong'o, 1982, pp. 203-204)

The peasants and workers are tired of the injustice in which they have lived many years since the British colonization and which allows a minority to suppress and exploit the majority, so they are ready to answer the call of Muturi to fight those exploiters and get rid of them. The masses are conscious that “...the real disturbers of the country's peace and stability are the thieves and robbers who dare to gather for a competition to show off their skills and strategies as far as looting people's goods is concerned" (Diaw, 2006, p. 80). 
Furthermore, although Wangari is humiliated, oppressed, and imprisoned, she represents a good example of the positive and resistant woman who cannot close her eyes as long as she sees a wrong deed. She puts her confidence in the Kenyan police thinking that they will catch the real thieves of the country. But unfortunately, she discovers that the police are just a sequential part of the corrupted Kenyan system that sponsors and advocates such absurd activities. As a result, according to Chijioke Uwasomba:

[a]lthough Wangari's action in inviting the police to arrest the rich robbers fails, it nevertheless helps the people in the course of their struggle for a new society, and teaches peasants and workers that the law is not the source of their salvation from capitalist exploitation, and as a result, it exists to sustain the status quo. (2006, p. 105)

After passing two years about the events of the devil's feast and chasing the thieves, Wariinga and Gatuiria decide to marry. They go to Nakuru in order for Wariinga to recognize Gatuiria's parents. On the other hand, Gatuiria's parents arrange a great party for receiving their son and his fiancée. The party of Gatuiria and Wariinga demonstrates Ngugi's ability to arouse the suspense and excitement of the readers. At the party, Wariinga is shocked when she finds that Gatuiria's father is the father of her girl. "Gatuiria's father? Wambui's father!" (Wa Thiong'o, 1982, p. 249). The omnipotence of the old man towards Wariinga in the past transforms presently to become a kind of humiliation and subservience. Mr. Ghitahy entreats Wariinga to leave his son and be his girl. Even in his state of weakness, Mr. Ghitahy cannot abandon his policy of exploitation. When Wariinga asks him if he will marry her, he replies "please, Jacinta, stop pretending that you don't understand. I am a man of the church. I just want you to be mine. I'll find my own ways of coming to visit you. Just like the old times, don't you remember? Please, save me! Save the honor of my name! (Wa Thiong'o, 1982, p. 253).

Apparently, Mr. Ghitahy occupies an influential position in the state, however, his deeds contradict with his appearance and pieces of advice. He deceives and exploits the youth of a young girl. He even impregnates her and then accuses her of prostitution. Knowing that he has a baby girl, he does not think about her even for a while. Besides, when he is put again in confrontation with Wariinga, the mother of his girl, he again 
presents his offer of more exploitation. He prefers to commit adultery and live with Wariinga in secret for the sake of saving the honor of his name and his home. "Therefore, in Ngugi's Devil on the Cross we see a progression in terms of the exploitation and the oppression of the African masses by African native leaders who now ruled and exploited their own people economically and sexually" (Marah, 1988, p. 192).

While the old man tries to beseech Wariinga to respond to his requests, Wariinga's reaction is unexpected. She opens her handbag, takes out a pistol, and kills Mr. Ghitahy. Then she finds two of the Kenyan thieves of Illmorog who are invited to the party outside the house. She remembers Wangari and Muturi and how they have been imprisoned since the chaos of the thieves' cave. Consequently, she has great anger that encourages her to shot both thieves, Kihaahu Wa Gatheeca and Gitutu Wa Gataanguru. Although Wariinga's last reaction seems clearly violent, it is considered also a kind of resistance. She revenges herself on the man who exploited her youth and destroyed her dreams and revenges the masses on the thieves who exploited their effort, sweat, and blood. Wariinga's reaction is a symbolism of eradicating and destroying the ruling human devils that represent the basic reason for other people's misery.

\section{Conclusion}

Actually, the writings of Ngugi Wa Thiong'o contribute highly to depicting the injustice and dishonesty of the postcolonial Kenyan regime. By choosing to write in Gikuyu, Ngugi intends to convey his voice and vision to the largest number of Kenyan people. Through shedding light on the effects of these features of corruption, he tries to wake up the consciousness and awareness of his people to the magnitude of their unity and struggle. In other words, he urges the masses not to succumb to their lamentable situation but to combat until they regain their stolen country.

\section{References}

Abis, P. (2011). Class struggle, elitism and social collectivism in Ngugi Wa Thiong'o's Devil on the cross: A Marxist approach. (Unpublished MA thesis). Dalarna University, Falun. Retrieved May 22, 2020 from https://cutt.ly/phPpnim 
Ashcroft, B., Gareth, G., and Tiffin, H. (2000). Post-colonial studies: The key concepts. London: Routledge.

Diaw, D. (2006). Elitism in Ngugi Wa Thiong'o's Devil on the cross and Petals of blood. Retrieved April 25, 2019, from https://bit.ly/35gZshD

Entwistle, H. (2001). Antonio Gramsci and the school as hegemonic. In J. Martin (Ed.), Antonio Gramsci: Critical assessments of leading political philosophers, Vol. III: Intellectuals, Culture and the Party (pp.225-266 ). London: Routledge.

Greenfield, K. (1995). Murdering the sleep of dictators: corruption, betrayal and the call to revolution in the works of Ngugi Wa Thiong'o. In C. Cantalupo (Ed.), The world of Ngugi Wa Thiong'o (pp. 27-43) Trenton: Africa World Press.

Harlow, B. (1987). Resistance literature. New York: Methuen.

Koussouhon, L. A., \& Amoussou, Y. C. (August 2015). Characterization, authority and ideology in Ngugi's Devil on the cross. Mediterranean Journal of Social Sciences, 6(4), 280-289. Retrieved March 25, 2019, from https://bit.ly/38jrwmB

Magray, A. U. H. (2019). Devil on the cross by Ngugi Wa Thiong'o: As a piece of political fiction and powerful critique of capitalism. Literaria, 9(1-2), 57-63. Retrieved April 22, 2020, from https://cutt.ly/yhPpxvc

Malembanie, N. K. (2011). Satirical art in Ngugi Wa Thiongo's novel Devil on the cross. Retrieved May 13, 2020, from http://bit.ly/3961BOq

Marah, J. K. (1988). African people in the global village: An introduction to pan African studies. Lanham: University Press of America.

Meenaskhi, M.S.S. (2019). Exposing corruption through grotesque image: A reading of Ngugi wa Thiong'o's Devil on the cross. Journal of the Gujarat Research Society, 21(10), 452-458. Retrieved November 28, 2019, from http://bit.ly/3om9uFI

Nicholls, B.. (2016). Ngugi Wa Thiong'o, gender, and the ethics of postcolonial reading. London: Routledge.

Dione, S., \& Diop, M. (2018). The rhetoric of irony in Ngugi wa Thiong'o's Devil on cross (1987) and Matigari (1980). International Journal of Language and Linguistics, 6(6), 223-230.

Sylla, N. (2009). Class struggle in Duboious battle (1936) by John Steinbeck and Devil on the Cross (1982) by Ngugi Wa Thiong'o. Memoire Online. Retrieved August 25, 2018, from https://cutt.ly/XhPpU4f

Swainson, N. (1980). The development of corporate capitalism in Kenya 1918-1977. Berkeley: UP of California.

Uwasomba, C. (2006, December). The politics of resistance and liberation in Ngugi Wa Thiong'o's Petals of blood and Devil on the cross. Journal of Pan African Studies, 1(6), 94-108. Retrieved July 28, 2019, from https://bit.ly/3rZFkKM

Wa Thiong'o, N. (1982). Devil on the cross. Johannesburg: Heinemann Educational Books.

Williams, J. E. (2000). Concealing class with race. In B. Lang (Ed.), Race \& racism in theory and practice (pp. 215-224 ) Lanham: Rowman \& Littlefield Publishers. 